Article

\title{
Combining Ability of Sixteen USA Maize Inbred Lines and Their Outbreeding Prospects in China
}

\author{
Ji-ying Sun ${ }^{1, *,+} \mathbb{C}$, Ju-lin Gao ${ }^{1, *+}{ }^{+}$, Xiao-fang Yu ${ }^{1,+}$, Jian Liu ${ }^{2,+}$, Zhi-jun Su ${ }^{1}$, Ye Feng ${ }^{3}$ and \\ Dong Wang ${ }^{3}$ \\ 1 College of Agronomy, Inner Mongolia Agricultural University, No.275, XinJian East Street, \\ Hohhot 010019, China; yuxiaofang75@163.com (X.-f.Y.); barrysu@126.com (Z.-j.S.) \\ 2 Vocational and Technical College, Inner Mongolia Agricultural University, Baotou 014109, China; \\ silentliujian@163.com \\ 3 Tongliao Academy of Agricultural Sciences, Qianjiadian, Tongliao 028015, China; \\ fengye810914@126.com (Y.F.); nkywd@126.com (D.W.) \\ * Correspondence: jiying-sun@imau.edu.cn (J.-y.S.); julin-gao@imau.edu.cn (J.-l.G.); \\ Tel.: +86-139-4713-0409 (J.-y.S. \& J.-l.G.) \\ + These authors contributed equally to this work.
}

Received: 29 October 2018; Accepted: 23 November 2018; Published: 27 November 2018

check for updates

\begin{abstract}
In China, there is an increasing need for greater genetic diversity in maize (Zea mays L.) germplasm and hybrids appropriate for mechanical harvesting. In order to test and distinguish American maize inbred lines with exceptional combining ability, four Chinese maize inbred lines (Chang7-2, Zheng 58, four-144 and four-287) were used to judge the combining ability and heterosis of 16 USA inbred lines by a NCII genetic mating method. The results showed that among the American inbred lines, 6M502A, LH208, NL001, LH212Ht, PHW51, FBLA and LH181 expressed good GCA for yield characteristics; while RS710, PHP76, FBLA, and PHJ89 showed excellent GCA for machine harvesting characteristics. Five hybrids (NL001 $\times$ Chang7-2, LH212Ht $\times$ Chang7-2, FBLA $\times$ four-144, LH181 $\times$ four-287, PHK93 $\times$ four-287) had better SCA values for yield characteristics, at 1.69, 1.07, 1.48, 1.84 and 1.05, respectively; while NL001 $\times$ Chang 7-2, 6M502A $\times$ Chang7-2, LH212Ht $\times$ Chang7-2, LH181 $\times$ four-287, PHW51 $\times$ Chang7-2 had better TCA values for yield characteristics, at 3.03, 2.80, 2.41, 2.19 and 1.91, respectively; NL001 $\times$ Chang7-2, 6M502A $\times$ Chang7-2, LH212Ht $\times$ Chang7-2, LH181 $\times$ four-287, PHW51 $\times$ Chang7-2 showed excellent Control Heterosis values, with $21.48 \%, 19.64 \%, 15.93 \%, 14.05 \%$ and $11.60 \%$ increases, respectively, compared to the check and potential for future utilization in Inner Mongolian corn production.
\end{abstract}

Keywords: USA inbred lines; combining ability; machine harvesting characteristics; yield characteristics; control heterosis

\section{Introduction}

The genetic diversity of maize germplasm in China is decreasing, due to fewer inbreds being used to produce modern, high-yielding maize hybrids. At the same time, the change of corn planting patterns in China has greatly increased the demand for full mechanization, which requires the improvement of maize varieties to be suitable for the machine harvesting of the grain. However, the lack of maize germplasm suitable for mechanical harvesting that has high combining ability, strong disease and pest resistance, and wide adaptability has become a bottleneck for maize breeding development in China [1-4]. North American germplasm plays an important role in China's corn yield potential, and their genetic contribution to Chinese corn has been increasing [5,6]. Using American maize germplasm is an effective way to improve the diversity of Chinese maize germplasm and 
screened favorable allele donors due to its clear genealogical origin and abundant genetic variation [7]. Previous studies have shown that the growth period, the silking stage, the ear height, the plant height, and the kernel moisture concentration at the R6 stage (physiological maturity) could be used to determine a maize germplasm suitable for mechanical harvesting [8]. General combining ability (GCA) is determined by the additive effects of genes, and can distinguish the genetic component of an inbred line and reflect its potential for utilization. Specific combining ability (SCA) is determined by the non-additive effect of genes, which is easily affected by the environment and cannot be stably inherited. It is used as a reference when sifting through hybrid combinations. The total combining ability (TCA) effect value is determined by the parental inbred GCA and SCA, it can be used as an index to evaluate combined hybrid performance. Control heterosis $(\mathrm{CH})$ is considered to be the yield-increasing index for corn varieties in the national standard of China, the best hybrid combination can be selected by analyzing the control heterosis. The research used 16 inbreds from the expired Plant Variety Protection Act (ex-PVP) germplasm adapted to the USA Corn Belt and germplasm currently used in Chinese production as the basic materials. The present study aimed to determine the germplasm most suitable for mechanical harvesting, and with the most favorable agronomic traits and yield-related traits, as well as the combining abilities of the lines, by analyzing their GCA, SCA, TCA and CH, so as to clarify the breeding potential of USA germplasm in the Inner Mongolian Maize production area, and provide a reference for its utilization.

\section{Materials and Methods}

\subsection{Germplasm and Experimental Sites}

Sixteen diverse maize expired Plant Variety Protection Act (ex-PVP) inbred germplasms adapted to the USA Corn Belt were acquired from the North Central Regional Plant Introduction Station (http:/ / www.ars-grin.gov/npgs, verified 24 August 2016), through the Maize Industrial Technology System Construction of Modem Agriculture of China by international communication.

The classification and pedigree sources of the sixteen USA inbreds and the four China inbreds are shown in Table 1. The China heterotic group A is similar to the USA heterotic group of stiff stalk synthetic (SS), while the China heterotic group B is similar to the USA heterotic group of non-stiff stalk synthetic (NSSS).

Table 1. Genealogical origin of USA maize inbred lines and China testers.

\begin{tabular}{cccc}
\hline Number & Germplasm & Heterotic Group & Genealogical Origin \\
\hline 1 & RS710 & NSS & $1202 \times 1250$ \\
2 & LH191 & SS & LH132 $\times$ Pioneer 3184 \\
3 & LH192 & SS & LHE137 $\times$ LHE136 \\
4 & PHN34 & SS & SC359 $\times$ PH157 specifically (SC359/PH157)X\#4221 \\
5 & PHP76 & NSS & $($ G50/PHEJ8)X812X \\
6 & PHW51 & SS & $($ PHDF2/PHG41)RXB333X \\
7 & FBLA & SS & (B14////Mt42).A656(B14//Mt42) \\
8 & 6F629 & NSS & 88051B /4608H \\
9 & NM502A & SS & MAWU.4913 \\
10 & NL001 & NSS & 1089HT $\times$ A634HT/B73 \\
11 & LH181 & SS & LH74 $\times$ CB59G \\
12 & LH208 & NSS & Mo17 $\times$ Lp216D \\
13 & LH212Ht & NSS & PHT77 $\times$ PHG47 \\
14 & Lp215D & NSS & LH123Ht $\times($ LH123Ht X LH24) \\
15 & PHJ89 & NSS & PHB72 $\times$ PHT60 specifically \\
16 & PHK93 & A & PHB72 $/$ PHT60)6K41K111K211 \\
17 & Zheng58 & B & V59 $\times$ Huangzaosi \\
18 & Chang7-2 & & \\
\hline
\end{tabular}


Table 1. Cont.

\begin{tabular}{cccc}
\hline Number & Germplasm & Heterotic Group & Genealogical Origin \\
\hline 19 & four-144 & A & VMA724 improved line \\
20 & four-287 & B & four-444 $\times 255$ \\
\hline
\end{tabular}

A is generally suitable to be the female parent with high yield, and A is similar to SS, B is generally suitable to be the male parent with more pollen, and B is similar to NSS.

The trials were conducted in 2015 at the two main Maize production areas of Inner Mongolia in China-Hohhot and Tongliao. The weather condition of 2015 and basis soil fertilizer are as below (Tables 2 and 3 ).

Table 2. Weather condition of 2015 in Hohhot and Tongliao.

\begin{tabular}{|c|c|c|c|c|c|}
\hline \multirow{2}{*}{ Experimental Sites } & \multirow{2}{*}{ Latitude } & \multirow{2}{*}{ Longitude } & Solar Radiation & Average Temperature & Precipitation \\
\hline & & & h per Year & ${ }^{\circ} \mathrm{C}$ & mm per Year \\
\hline Hohhot & $40^{\circ} 33^{\prime} \mathrm{N}$ & $110^{\circ} 31^{\prime} \mathrm{E}$ & 1780.5 & 17.8 & 275.4 \\
\hline Tongliao & $43^{\circ} 42^{\prime} \mathrm{N}$ & $122^{\circ} 32^{\prime} \mathrm{E}$ & 1224.7 & 20.5 & 433.2 \\
\hline
\end{tabular}

Table 3. Basis fertilizer of soil in Hohhot and Tongliao.

\begin{tabular}{cccccc}
\hline \multirow{2}{*}{ Experimental Sites } & Organic Matter & Available N & Available P & Available K & \multirow{2}{*}{ Soil Type } \\
\cline { 2 - 5 } & $\mathbf{g} / \mathbf{k g}$ & $\mathbf{m g} / \mathbf{k g}$ & $\mathbf{m g} / \mathbf{k g}$ & $\mathbf{m g} / \mathbf{k g}$ & \\
\hline Hohhot & 18.9 & 44.8 & 16.2 & 120.4 & Sandy loam \\
Tongliao & 20.4 & 55.6 & 18.2 & 167.9 & $\begin{array}{c}\text { Meadow } \\
\text { chernozemic soil }\end{array}$ \\
\hline
\end{tabular}

\subsection{Experimental Design}

Hybrids were produced using the sixteen USA maize inbred lines as female parents and the four China test species as male parents. In a NC-II genetic mating design, 64 hybrid combinations were produced at Hainan province Ledong county experimental base $\left(18^{\circ} 45^{\prime} 5.38^{\prime \prime} \mathrm{N}, 109^{\circ} 10^{\prime} 10.22^{\prime \prime} \mathrm{E}\right)$ in the winter of 2014.

In 2015, the 64 hybrid combinations and one control hybrid (Zhengdan 958) were planted at Hohhot and Tongliao. An $\alpha$-lattice block design was used with five replications, $0.6 \mathrm{~m}$ row spacing, $0.25 \mathrm{~m}$ plant spacing, 40 plants per plot, with a density of 66,670 plants $/$ ha. Two row plots. The rate of NPK fertilizer applied was N: $200 \mathrm{~kg} / \mathrm{ha}, \mathrm{P}_{2} \mathrm{O}_{5}: 105 \mathrm{~kg} / \mathrm{ha}$ and $\mathrm{K}_{2} \mathrm{O}: 62 \mathrm{~kg} / \mathrm{ha}$. Phosphate fertilizer and potash fertilizer were applied as basal fertilizer once before planting and nitrogen fertilizer was applied by $30 \%(60 \mathrm{~kg} / \mathrm{ha})$ at V6 stage (six leaves with collars visible) and $70 \%(140 \mathrm{~kg} / \mathrm{ha})$ at V12 stage (twelve leaves with collars visible), respectively. Irrigation and other management measures during the whole growth period were similar to local farmer practices.

\subsection{Measurements and Production Indicators}

The days from field emergence to $50 \%$ silking and to maturity were recorded for each plot. During plant maturation, 10 plants were randomly selected, and their total height and ear height were measured.

Plant stand counts were tallied to confirm plant populations at the R6 plant growth stage, and ear stand counts were tallied to confirm ear number per ha. The two rows of each plot were manually harvested for determination of grain yield at physiological maturity, corn ears were tallied and weighed, the grain was removed manually to analyze for moisture content using seed moisture meter (PM-8188-A, KETT ELECTRIC LABORATORY, Tokyo, Japan), 300 randomly selected kernels were weighed to estimate average individual kernel weight. According to the average weight of the ear, 
select 10 ears of each plot to assess the number of rows per ear and grain number per row. The kernel weight and the yield were presented at $14 \%$ moisture content.

\subsection{Data Statistical Analysis}

Variance analysis of all the traits collected including the General and Specific Combining Abilities was performed by GLM of SAS software version [9], linear model was as followed [10]:

$$
\mathrm{Y}_{i j k}=\mu+\mathrm{m}_{i}+\mathrm{f}_{j}+(\mathrm{m} \times \mathrm{f})_{i j}+\mathrm{e}_{i j k}
$$

where $Y_{i j k}$ is the $k$ observational value of the progeny of parents $i$ and $j, \mu$ is the universal mean, $\mathrm{m}_{i}$ is $i$-th paternity effect, $\mathrm{f}_{j}$ is $j$-th maternal effect, $(\mathrm{m} \times \mathrm{f})_{i j}$ is the interaction effect, $\mathrm{e}_{i j k}$ is the error term.

$$
\mathrm{TCA}_{i j}=\mathrm{G}_{i}+\mathrm{G}_{j}+\mathrm{S}_{i j}
$$

where $\mathrm{TCA}_{i j}$ is Total Combining Ability of the progeny of parents $i$ and $j, \mathrm{G}_{i}$ is General Combining Ability of parent $i, \mathrm{G}_{j}$ is General Combining Ability of parent $j, S_{i j}$ is Special Combining Ability of the progeny of parents $i$ and $j$.

$$
\mathrm{CH}_{i j}=\left(\mathrm{YF}_{i j}-\mathrm{YC}\right) / \mathrm{YC} \times 100 \%
$$

where $\mathrm{CH}_{i j}$ is the Control Heterosis of the progeny of parents $i$ and $j, \mathrm{YF}_{i j}$ is the average yield of an individual hybrid combination by parents $i$ and $j, \mathrm{YC}$ is the average yield of the control Zhengdan 958 .

\section{Results}

\subsection{Field Characteristic and Adaptability of the Trial Inbreds}

Throughout the 2014 trial of field adaption, the sixteen USA ex-PVP inbred germplasms showed excellent adaption characteristics to the weather and soil condition in the two main production areas of Maize in Inner Mongolia-Hohhot (Table 4) and Tongliao (Table 5).

From Table 4, it can be seen that the days to silking of the Sixteen USA inbreds was 63-82 days, respectively, after the emergence, the days to maturity of the sixteen inbreds were 111-126 days, respectively; the plant height of the sixteen inbreds was 120-260 cm, respectively; the ear height was 39-100 cm, respectively; ASI (anthesis-silking interval) was -1 to -3 , respectively, and the overall merit of adaptability was 4-8, respectively. From Table 5, we can see that the days to silking of the sixteen USA inbreds was 51-67 days, respectively, after emergence; the days to maturity of the sixteen inbreds was 112-123 days, respectively; the plant height was 140-246 cm, respectively; the ear height was 34-100 cm, respectively; the ASI was 0 to -3 , respectively; and the overall merit of adaptability was 4 to 8 , respectively. The field characteristics of the sixteen USA inbreds in Hohhot and Tongliao were suitable for acting as a hybrid parent together with the four China inbreds, and based on the adaptability of the sixteen inbreds to the conditions in Hohhot and Tongliao, the inbreds can adapt to grow in the Inner Mongolian maize production areas, so this study select the sixteen USA ex-PVP inbred germplasms and the 4 China test lines as trial materials.

\subsection{Phenotypic and Grain Yield Traits}

The machine-harvest characteristics of the maize hybrids in the different locations varied greatly. At Hohhot, the days to maturity between hybrids differed by 13 , while at Tongliao hybrids matured over 33 days. The days to silking at Hohhot varied by 18 days, but that at Tongliao by 12 days. Plants were shorter, but with less variability at Hohhot, ranging from 159.5 to $278.8 \mathrm{~cm}$. Meanwhile, at Tongliao, plant height ranged from 202.0 to $324.0 \mathrm{~cm}$. Ear height of the hybrids at Hohhot was $47.5-116.0 \mathrm{~cm}$, and that at Tongliao was $71.0-158.0 \mathrm{~cm}$. At harvest time, the grain moisture content varied from $18.6 \%$ to $38.6 \%$ at Hohhot, and from $24.2 \%$ to $35.3 \%$ at Tongliao (Table 6 ). 
A basic statistical analysis of the hybrid yield-based indicators of ear row number, kernel grains per row, 100-kernel weight and grain yield carried out at Hohhot and Tongliao (Table 7) showed that the extremes, average, standard deviation and variable coefficient of the measured traits at the different locations varied greatly. There was a greater range in kernel grains per row at Hohhot-from 29.5 to 46.5-compared to 32.1 to 42.6 at Tongliao. At Hohhot, ear row number varied from 11.6 to 18.0, with slightly more at Tongliao, from 12.8 to 18.4 . 
Table 4. Field characteristic and adaptability of the sixteen USA inbreds and four China inbreds in Hohhot. Values are the average \pm 1 standard error.

\begin{tabular}{|c|c|c|c|c|c|c|c|c|c|c|c|}
\hline \multirow[t]{2}{*}{ Number } & \multirow[t]{2}{*}{ Inbred } & $\begin{array}{l}\text { Days to } \\
\text { Silking }\end{array}$ & $\begin{array}{l}\text { Days to } \\
\text { Maturity }\end{array}$ & ASI & $\begin{array}{c}\text { Plant } \\
\text { Height }\end{array}$ & Ear Height & \multirow[t]{2}{*}{$\begin{array}{l}\text { Seeding } \\
\text { Potential }\end{array}$} & \multirow[t]{2}{*}{$\begin{array}{c}\text { Disease } \\
\text { Resistance (R6) }\end{array}$} & \multirow[t]{2}{*}{$\begin{array}{c}\text { Anti- } \\
\text { Lodging }\end{array}$} & \multirow[t]{2}{*}{$\begin{array}{c}\text { Ear } \\
\text { Evaluation }\end{array}$} & \multirow[t]{2}{*}{$\begin{array}{c}\text { Overall } \\
\text { Merit }\end{array}$} \\
\hline & & Day & Day & Day & $\mathrm{cm}$ & $\mathrm{cm}$ & & & & & \\
\hline 1 & RS710 & $72 \pm 0.8$ & $118 \pm 0.7$ & $-2 \pm 0.8$ & $182 \pm 4.1$ & $55 \pm 2.6$ & $1^{+}$ & $2 \ddagger$ & $1 \S$ & $3^{\mathbb{I I}}$ & $7^{\varnothing}$ \\
\hline 2 & LH191 & $78 \pm 0.5$ & $126 \pm 1.4$ & $-2 \pm 0.8$ & $260 \pm 8.4$ & $100 \pm 5.0$ & 1 & 2 & 1 & 3 & 7 \\
\hline 3 & LH192 & $79 \pm 0.9$ & $125 \pm 0.7$ & $-3 \pm 0.7$ & $200 \pm 12.9$ & $78 \pm 2.5$ & 1 & 2 & 1 & 3 & 7 \\
\hline 4 & PHN34 & $76 \pm 0.4$ & $124 \pm 0.0$ & $-2 \pm 0.9$ & $180 \pm 3.7$ & $79 \pm 4.0$ & 1 & 1 & 1 & 2 & 5 \\
\hline 5 & PHP76 & $72 \pm 0.4$ & $117 \pm 0.0$ & $-3 \pm 0.5$ & $165 \pm 3.6$ & $60 \pm 1.5$ & 1 & 1 & 1 & 3 & 6 \\
\hline 6 & PHW51 & $74 \pm 1.1$ & $122 \pm 0.4$ & $-2 \pm 1.1$ & $198 \pm 13.2$ & $85 \pm 3.5$ & 1 & 2 & 1 & 1 & 5 \\
\hline 7 & FBLA & $74 \pm 0.4$ & $119 \pm 0.0$ & $-1 \pm 0.9$ & $181 \pm 7.0$ & $79 \pm 2.5$ & 1 & 1 & 1 & 1 & 4 \\
\hline 8 & 6F629 & $75 \pm 0.9$ & $119 \pm 0.9$ & $-1 \pm 0.4$ & $202 \pm 6.9$ & $87 \pm 2.2$ & 1 & 3 & 1 & 3 & 8 \\
\hline 9 & $6 \mathrm{M} 502 \mathrm{~A}$ & $76 \pm 0.5$ & $118 \pm 0.0$ & $-3 \pm 0.8$ & $243 \pm 6.5$ & $100 \pm 3.2$ & 1 & 1 & 1 & 1 & 4 \\
\hline 10 & NL001 & $75 \pm 0.8$ & $111 \pm 0.0$ & $-3 \pm 0.8$ & $210 \pm 5.8$ & $80 \pm 2.2$ & 1 & 1 & 1 & 1 & 4 \\
\hline 11 & LH181 & $77 \pm 0.5$ & $122 \pm 0.4$ & $-2 \pm 0.5$ & $228 \pm 5.7$ & $75 \pm 2.8$ & 1 & 1 & 2 & 1 & 5 \\
\hline 12 & LH208 & $82 \pm 0.0$ & $118 \pm 0.9$ & $-2 \pm 0.5$ & $134 \pm 6.8$ & $48 \pm 2.6$ & 1 & 1 & 1 & 1 & 4 \\
\hline 13 & LH212Ht & $71 \pm 0.4$ & $122 \pm 0.0$ & $-2 \pm 0.4$ & $195 \pm 2.6$ & $70 \pm 1.4$ & 1 & 1 & 1 & 1 & 4 \\
\hline 14 & Lp215D & $81 \pm 0.5$ & $116 \pm 0.4$ & $-2 \pm 0.5$ & $190 \pm 8.2$ & $70 \pm 3.2$ & 1 & 1 & 1 & 1 & 4 \\
\hline 15 & PHJ89 & $63 \pm 0.4$ & $119 \pm 0.9$ & $-2 \pm 0.4$ & $120 \pm 4.1$ & $39 \pm 2.2$ & 1 & 2 & 1 & 1 & 5 \\
\hline 16 & PHK93 & $79 \pm 0.5$ & $123 \pm 0.0$ & $-2 \pm 0.8$ & $185 \pm 7.6$ & $50 \pm 1.5$ & 1 & 2 & 1 & 1 & 5 \\
\hline 17 & Zheng58 & $74 \pm 0.5$ & $126 \pm 0.9$ & $-2 \pm 0.5$ & $175 \pm 4.5$ & $80 \pm 4.5$ & 1 & 1 & 2 & 1 & 5 \\
\hline 18 & Chang7-2 & $73 \pm 0.5$ & $123 \pm 0.0$ & $0 \pm 0.8$ & $145 \pm 8.2$ & $38 \pm 2.3$ & 2 & 1 & 1 & 1 & 5 \\
\hline 19 & Four-144 & $69 \pm 1.1$ & $119 \pm 1.1$ & $-2 \pm 1.5$ & $178 \pm 3.8$ & $55 \pm 1.9$ & 1 & 1 & 2 & 1 & 5 \\
\hline 20 & Four-287 & $68 \pm 0.5$ & $120 \pm 0.5$ & $0 \pm 0.5$ & $156 \pm 4.0$ & $46 \pm 1.1$ & 1 & 2 & 1 & 1 & 5 \\
\hline
\end{tabular}

Sowing date: 2 May 2014. Emergence date: 15 May 2014; ${ }^{\dagger}$ means the estimate of the seeding potential, with $1-5$ representing the seeding potential from the best to the worst; ${ }^{\ddagger}$ means the estimate of the disease resistance in R6 growth stage, with 1-5 representing the disease resistance from the best to the worst; ${ }^{\$}$ means the estimate of the Anti-lodging, with $1-5$ representing the Anti-lodging characteristic from the best to the worst; ${ }^{\text {II }}$ means the ear evaluation, with 1-5 representing from the best ear characteristic and yield potential to the worst; ${ }^{\complement}{ }^{~ m e a n s}$ the sum of seeding potential, disease resistance, Anti-lodging, and ear evaluation; the lower the amount, the better the overall merit. 
Table 5. Field characteristics and adaptability of the sixteen USA inbreds and four China inbreds in Tongliao. Values are the average \pm 1 standard error.

\begin{tabular}{|c|c|c|c|c|c|c|c|c|c|c|c|}
\hline \multirow[t]{2}{*}{ Number } & \multirow[t]{2}{*}{ Inbred } & $\begin{array}{l}\text { Days to } \\
\text { Silking }\end{array}$ & $\begin{array}{c}\text { Days to } \\
\text { Maturity }\end{array}$ & ASI & $\begin{array}{c}\text { Plant } \\
\text { Height }\end{array}$ & Ear Height & \multirow[t]{2}{*}{$\begin{array}{l}\text { Seeding } \\
\text { Potential }\end{array}$} & \multirow[t]{2}{*}{$\begin{array}{c}\text { Disease } \\
\text { Resistance (R6) }\end{array}$} & \multirow[t]{2}{*}{$\begin{array}{c}\text { Anti- } \\
\text { Lodging }\end{array}$} & \multirow[t]{2}{*}{$\begin{array}{c}\text { Ear } \\
\text { Evaluation }\end{array}$} & \multirow[t]{2}{*}{$\begin{array}{c}\text { Overall } \\
\text { Merit }\end{array}$} \\
\hline & & Day & Day & Day & $\mathrm{cm}$ & $\mathrm{cm}$ & & & & & \\
\hline 1 & RS710 & $51 \pm 0.5$ & $112 \pm 0.5$ & $-1 \pm 0.0$ & $140 \pm 3.9$ & $34 \pm 1.0$ & $1^{+}$ & $3 \ddagger$ & $1 \S$ & $3^{\mathbb{I I}}$ & $8^{4}$ \\
\hline 2 & LH191 & $67 \pm 0.5$ & $123 \pm 0.9$ & $-1 \pm 0.0$ & $172 \pm 4.1$ & $56 \pm 1.5$ & 1 & 2 & 1 & 2 & 6 \\
\hline 3 & LH192 & $66 \pm 0.5$ & $120 \pm 0.0$ & $-2 \pm 0.5$ & $175 \pm 3.6$ & $58 \pm 1.5$ & 1 & 3 & 1 & 2 & 7 \\
\hline 4 & PHN34 & $63 \pm 1.1$ & $122 \pm 0.0$ & $-1 \pm 0.5$ & $210 \pm 7.6$ & $82 \pm 2.0$ & 1 & 2 & 1 & 2 & 6 \\
\hline 5 & PHP76 & $55 \pm 0.5$ & $116 \pm 1.1$ & $0 \pm 0.9$ & $171 \pm 3.3$ & $55 \pm 1.5$ & 1 & 2 & 1 & 3 & 7 \\
\hline 6 & PHW51 & $63 \pm 0.5$ & $122 \pm 0.5$ & $0 \pm 0.5$ & $205 \pm 4.1$ & $60 \pm 3.5$ & 1 & 2 & 1 & 2 & 6 \\
\hline 7 & FBLA & $58 \pm 1.0$ & $118 \pm 0.5$ & $-3 \pm 1.3$ & $181 \pm 1.9$ & $45 \pm 1.0$ & 1 & 2 & 1 & 1 & 5 \\
\hline 8 & $6 \mathrm{~F} 629$ & $58 \pm 0.4$ & $115 \pm 1.1$ & $0 \pm 0.7$ & $206 \pm 4.7$ & $78 \pm 0.6$ & 1 & 1 & 1 & 3 & 6 \\
\hline 9 & $6 \mathrm{M} 502 \mathrm{~A}$ & $63 \pm 0.5$ & $117 \pm 0.0$ & $-2 \pm 0.8$ & $207 \pm 2.6$ & $73 \pm 1.5$ & 1 & 1 & 1 & 1 & 4 \\
\hline 10 & NL001 & $62 \pm 0.4$ & $115 \pm 0.4$ & $-2 \pm 0.4$ & $160 \pm 5.8$ & $63 \pm 0.6$ & 1 & 1 & 1 & 1 & 4 \\
\hline 11 & LH181 & $61 \pm 0.4$ & $118 \pm 0.5$ & $-1 \pm 0.7$ & $246 \pm 7.9$ & $72 \pm 4.5$ & 1 & 1 & 1 & 1 & 4 \\
\hline 12 & LH208 & $65 \pm 0.8$ & $120 \pm 0.4$ & $-2 \pm 0.5$ & $225 \pm 3.2$ & $75 \pm 2.0$ & 1 & 1 & 1 & 1 & 4 \\
\hline 13 & LH212Ht & $64 \pm 0.5$ & $122 \pm 0.5$ & $-2 \pm 0.8$ & $245 \pm 4.6$ & $100 \pm 6.5$ & 1 & 1 & 1 & 2 & 5 \\
\hline 14 & Lp215D & $56 \pm 0.8$ & $118 \pm 0.4$ & $0 \pm 0.8$ & $212 \pm 2.6$ & $60 \pm 0.6$ & 1 & 2 & 1 & 1 & 5 \\
\hline 15 & PHJ89 & $53 \pm 0.9$ & $115 \pm 1.1$ & $-1 \pm 1.3$ & $210 \pm 3.2$ & $63 \pm 1.0$ & 1 & 2 & 1 & 2 & 6 \\
\hline 16 & PHK93 & $64 \pm 0.5$ & $115 \pm 1.1$ & $-1 \pm 0.4$ & $205 \pm 4.0$ & $55 \pm 1.5$ & 1 & 1 & 1 & 2 & 5 \\
\hline 17 & Zheng58 & $66 \pm 0.5$ & $120 \pm 0.9$ & $-2 \pm 0.4$ & $189 \pm 6.1$ & $81 \pm 0.6$ & 1 & 1 & 2 & 1 & 5 \\
\hline 18 & Chang7-2 & $65 \pm 0.5$ & $121 \pm 0.5$ & $-1 \pm 0.5$ & $154 \pm 3.2$ & $47 \pm 2.0$ & 1 & 1 & 1 & 1 & 4 \\
\hline 19 & Four-144 & $57 \pm 0.5$ & $116 \pm 0.0$ & $1 \pm 0.9$ & $170 \pm 2.1$ & $52 \pm 0.6$ & 1 & 1 & 2 & 1 & 5 \\
\hline 20 & Four-287 & $58 \pm 0.4$ & $115 \pm 0.4$ & $1 \pm 0.4$ & $152 \pm 2.9$ & $43 \pm 1.5$ & 1 & 2 & 1 & 1 & 5 \\
\hline
\end{tabular}

Sowing date: 1 May 2014.Emergence date: 14 May 2014; ${ }^{\dagger}$ means the estimate of the seeding potential, with 1-5 representing the seeding potential from the best to the worst; ${ }^{\ddagger}$ means the estimate of the disease resistance in R6 growth stage, with 1-5 representing the disease resistance from the best to the worst; ${ }^{\$}$ means the estimate of the Anti-lodging, with $1-5$ representing the Anti-lodging characteristic from the best to the worst; ${ }^{\text {II }}$ means the ear evaluation, with 1-5 representing from the best ear characteristic and yield potential to the worst; ${ }^{\complement}{ }^{~ m e a n s ~ t h e ~}$ sum of seeding potential, disease resistance, Anti-lodging, and ear evaluation; the lower the amount, the better the overall merit. 
Table 6. Summary of machine-harvesting-related trait measurements for 64 maize hybrids grown in Hohhot and Tongliao in 2015.

\begin{tabular}{|c|c|c|c|c|c|c|c|c|c|c|}
\hline & \multicolumn{5}{|c|}{ Hohhot } & \multicolumn{5}{|c|}{ Tongliao } \\
\hline & $\begin{array}{l}\text { Days to } \\
\text { Maturity }\end{array}$ & $\begin{array}{l}\text { Days to } \\
\text { Silking }\end{array}$ & $\begin{array}{c}\text { Plant } \\
\text { Height }\end{array}$ & Ear Height & $\begin{array}{c}\text { Grain } \\
\text { Moisture }\end{array}$ & $\begin{array}{l}\text { Days to } \\
\text { Maturity }\end{array}$ & $\begin{array}{l}\text { Days to } \\
\text { Silking }\end{array}$ & $\begin{array}{l}\text { Plant } \\
\text { Height }\end{array}$ & Ear Height & $\begin{array}{c}\text { Grain } \\
\text { Moisture }\end{array}$ \\
\hline & Day & Day & $\mathrm{cm}$ & $\mathrm{cm}$ & $\%$ & Day & Day & $\mathrm{cm}$ & $\mathrm{cm}$ & $\%$ \\
\hline minimum & 136.0 & 66.0 & 159.5 & 47.5 & 18.6 & 105.0 & 55.0 & 202.0 & 71.0 & 24.2 \\
\hline maximum & 149.0 & 84.0 & 278.8 & 116.0 & 38.6 & 138.0 & 67.0 & 324.0 & 158.0 & 35.3 \\
\hline SD & 0.65 & 0.97 & 7.25 & 3.05 & 0.80 & 0.57 & 0.83 & 11.10 & 4.86 & 0.96 \\
\hline average & 144.7 & 77.1 & 225.0 & 75.4 & 29.9 & 121.7 & 61.4 & 280.0 & 110.0 & 28.6 \\
\hline $\mathrm{CV}$ & 0.45 & 1.26 & 3.22 & 4.05 & 2.69 & 0.47 & 1.34 & 3.96 & 4.42 & 3.37 \\
\hline
\end{tabular}

Table 7. Summary of yield-related trait measurements for 64 maize hybrids grown in Hohhot and Tongliao in 2015.

\begin{tabular}{|c|c|c|c|c|c|c|c|c|}
\hline & \multicolumn{4}{|c|}{ Hohhot } & \multicolumn{4}{|c|}{ Tongliao } \\
\hline & \multirow{2}{*}{$\begin{array}{c}\text { Kernels per } \\
\text { Row }\end{array}$} & \multirow[t]{2}{*}{ Rows per Ear } & \multirow{2}{*}{$\begin{array}{c}\begin{array}{c}\text { 100-Kernel } \\
\text { Weight }\end{array} \\
\mathrm{g} \\
\end{array}$} & \multirow{2}{*}{$\begin{array}{c}\text { Grain Yield } \\
\text { t/ha }\end{array}$} & \multirow{2}{*}{$\begin{array}{c}\text { Kernels per } \\
\text { Row }\end{array}$} & \multirow[t]{2}{*}{ Rows per Ear } & \multirow{2}{*}{$\begin{array}{c}\begin{array}{c}\text { 100-Kernel } \\
\text { Weight }\end{array} \\
\mathrm{g} \\
\end{array}$} & \multirow{2}{*}{$\begin{array}{c}\text { Grain Yield } \\
\text { t/ha }\end{array}$} \\
\hline & & & & & & & & \\
\hline minimum & 29.5 & 11.6 & 23.6 & 6.5 & 32.1 & 12.8 & 26.7 & 7.7 \\
\hline maximum & 46.5 & 18.0 & 39.6 & 15.3 & 42.6 & 18.4 & 41.0 & 16.8 \\
\hline SD & 0.37 & 0.27 & 0.75 & 0.65 & 0.56 & 0.29 & 0.86 & 0.88 \\
\hline average & 39.3 & 14.3 & 30.7 & 11.0 & 38.7 & 15.9 & 33.5 & 11.4 \\
\hline $\mathrm{CV}$ & 0.95 & 1.93 & 2.46 & 5.97 & 1.43 & 1.83 & 2.56 & 7.74 \\
\hline
\end{tabular}

At Hohhot, 100-kernel weight of the hybrids was lighter, and varied from $23.6 \mathrm{~g}$ to $39.6 \mathrm{~g}$, compared to at Tongliao, which was $26.7 \mathrm{~g}$ to $41.0 \mathrm{~g}$. There was a large variation in grain yield of the hybrids, $6.5 \mathrm{t} / \mathrm{ha}-15.7 \mathrm{t} / \mathrm{ha}$ and $7.7 \mathrm{t} / \mathrm{ha}-16.8 \mathrm{t} / \mathrm{ha}$ at Hohhot and Tongliao, respectively. 


\subsection{Analysis of Variance of Main Characteristics}

Table 8 shows that the variances of five traits relating to the suitability of harvesting (the days to maturity, days to silking, plant height, ear height and moisture content at harvest) in paternal tester's heterosis, general combining ability (GCA) and specific combining ability (SCA) of maternal lines were all significant or highly significant. The environmental and gene interaction effects of all traits were highly significant.

Table 8. Analysis of variance for the machine-harvesting characteristics of the hybrids derived from USA maize inbred lines crossed with China inbred testers grown in two locations in 2015.

\begin{tabular}{|c|c|c|c|c|c|c|}
\hline Variation Source & DF & $\begin{array}{l}\text { Days to } \\
\text { Maturity }\end{array}$ & $\begin{array}{l}\text { Days to } \\
\text { Silking }\end{array}$ & $\begin{array}{l}\text { Plant } \\
\text { Height }\end{array}$ & Ear Height & $\begin{array}{c}\text { Grain } \\
\text { Moisture at } \\
\text { Harvest }\end{array}$ \\
\hline Environment & 1 & $50,669.1 * *$ & $23,531.3 * *$ & $290,554.0$ ** & $115,065.8^{* *}$ & $155.3^{* *}$ \\
\hline Line & 15 & $166.2^{* *}$ & $134.8^{* *}$ & $3133.8 * *$ & 801.0 ** & $49.4^{* *}$ \\
\hline Tester & 3 & $467.4^{* *}$ & $158.4^{* *}$ & $22,005.8^{* *}$ & $15,824.8^{* *}$ & $118.3^{* *}$ \\
\hline Line $\times$ Tester & 45 & $56.6^{* *}$ & $12.3^{* *}$ & $390.0^{* *}$ & $350.8 * *$ & $22.3^{* *}$ \\
\hline Line $\times$ Environment & 15 & $69.6^{* *}$ & $30.1 * *$ & $516.3^{* *}$ & $167.3^{* *}$ & $29.3 * *$ \\
\hline Tester $\times$ Environment & 3 & $316.5^{* *}$ & $2.7 *$ & $2255.1^{* *}$ & $344.4 * *$ & $19.6^{* *}$ \\
\hline Line $\times$ Tester $\times$ Environment & 45 & $55.3 * *$ & $8.6^{* *}$ & $504.9 * *$ & $363.0 * *$ & $30.2 * *$ \\
\hline
\end{tabular}

${ }^{*}$ and ${ }^{* *}$ in the column represents significance at the 0.05 and 0.01 probability level, respectively.

The four grain yield characteristics (kernel grains per row, the ear row number, 100-kernel weight and grain yield) expressed significant differences for line, tester, environment, and between the interaction (Table 9).

Table 9. Analysis of variance for the yield characteristics of the hybrids derived from USA maize inbred lines crossed with China inbred testers grown in two locations in 2015.

\begin{tabular}{|c|c|c|c|c|c|}
\hline Variation Source & DF & $\begin{array}{c}\text { Kernel } \\
\text { Number per } \\
\text { Row }\end{array}$ & $\begin{array}{c}\text { Kernel Row } \\
\text { Number }\end{array}$ & $\begin{array}{c}\text { 100-Kernel } \\
\text { Weight }\end{array}$ & Grain Yield \\
\hline Environment & 1 & $29.4^{* *}$ & $248.7 * *$ & $755.0 * *$ & $16.0^{* *}$ \\
\hline Line & 15 & $60.8^{* *}$ & $4.7^{* *}$ & $47.8^{* *}$ & $14.5^{* *}$ \\
\hline Tester & 3 & $187.4^{* *}$ & $41.6^{* *}$ & $279.4^{* *}$ & $36.6^{* *}$ \\
\hline Line $\times$ Tester & 45 & $12.6^{* *}$ & $1.7^{* *}$ & $18.9 * *$ & $3.7 * *$ \\
\hline Line $\times$ Environment & 15 & $16.2 * *$ & $2.8 * *$ & $17.3^{* *}$ & $4.4^{* *}$ \\
\hline Tester $\times$ Environment & 3 & $32.2 * *$ & $1.6^{* *}$ & $14.6^{* *}$ & $2.7^{* *}$ \\
\hline Line $\times$ Tester $\times$ Environment & 45 & $6.7^{* *}$ & $0.7^{* *}$ & $18.0^{* *}$ & $2.6^{* *}$ \\
\hline
\end{tabular}

${ }^{* *}$ in the column represents significance at the 0.01 probability level, respectively.

\subsection{General Combining Ability (GCA) Effect of USA Inbred Lines Suitable for Machine-Harvest Indexes and} Grain Yield Characters

The GCA effect of both days to maturity and days to silking were significantly negative for RS710, PHP76, FBLA, 6F629, NL001, Lp215D and PHJ89, indicating that hybrids derived from these inbred lines had faster development, with shorter days to silking and to maturity (Table 10). Hybrids made from RS710, PHP76, FBLA, or PHJ89 resulted in shorter plants with lower ear heights, displaying lower GCA effect values. Additionally, the negative GCA effect values of grain water content at harvest of RS710, PHP76, FBLA, 6F629, LH208 and PHJ89, indicates that hybrids derived from these inbred lines had a faster grain dehydration rate (Table 10). 
Table 10. The general combining ability of USA inbred lines for machine-harvest and yield characteristics.

\begin{tabular}{|c|c|c|c|c|c|c|c|c|c|}
\hline Line & $\begin{array}{l}\text { Days to } \\
\text { Maturity }\end{array}$ & $\begin{array}{l}\text { Days to } \\
\text { Silking }\end{array}$ & Plant Height & Ear Height & $\begin{array}{c}\text { Grain Moisture at } \\
\text { Harvest }\end{array}$ & $\begin{array}{l}\text { Kernels per } \\
\text { Row }\end{array}$ & Kernel Rows & $\begin{array}{c}\text { 100-Kernel } \\
\text { Weight }\end{array}$ & Grain Yield \\
\hline RS710 & $-4.96^{* *}$ & $-5.47^{* *}$ & $-34.33^{* *}$ & $-13.96^{* *}$ & $-2.91^{* *}$ & $-4.85^{* *}$ & -0.04 & $-1.47^{* *}$ & $-1.97 * *$ \\
\hline LH191 & $3.04^{* *}$ & $2.57^{* *}$ & $-3.72 * *$ & -0.85 & 0.10 & $-0.77^{* *}$ & $0.18^{* *}$ & $1.20 * *$ & $-0.31^{* *}$ \\
\hline LH192 & $4.41^{* *}$ & $2.73 * *$ & $4.93^{* *}$ & $1.57^{*}$ & $1.89 * *$ & $0.60 * *$ & $0.76^{* *}$ & $-0.66^{* *}$ & $-0.49 * *$ \\
\hline PHN34 & $3.50 * *$ & $2.07 * *$ & $13.54^{* *}$ & $11.26^{* *}$ & $2.06^{* *}$ & $0.67^{* *}$ & $-0.09 *$ & 0.11 & -0.28 * \\
\hline PHP76 & $-1.88^{* *}$ & $-3.35^{* *}$ & $-13.09 * *$ & $-2.13^{* *}$ & $-0.86^{* *}$ & $0.59 * *$ & -0.04 & $-2.07^{* *}$ & -0.56 ** \\
\hline PHW51 & $1.71^{* *}$ & $0.69 * *$ & 0.14 & -0.26 & $1.32^{* *}$ & 0.10 & $-0.33^{* *}$ & $-0.70 * *$ & $0.48^{* *}$ \\
\hline FBLA & $-1.75^{* *}$ & $-1.68^{* *}$ & $-2.68 *$ & $-5.34^{* *}$ & $-2.43^{* *}$ & $-0.19 * *$ & $-0.41^{* *}$ & $1.49^{* *}$ & $0.42 * *$ \\
\hline 6F629 & $-1.04^{* *}$ & $-0.27^{*}$ & -0.96 & -0.37 & $-1.33^{* *}$ & $1.01^{* *}$ & $-0.11^{* *}$ & $-2.20^{* *}$ & $-0.63 * *$ \\
\hline $6 \mathrm{M} 502 \mathrm{~A}$ & $-1.25^{* *}$ & $2.23^{* *}$ & $7.55^{* *}$ & $6.57 * *$ & $1.43^{* *}$ & $1.01^{* *}$ & $-0.41^{* *}$ & $-0.99 * *$ & $1.47^{* *}$ \\
\hline NL001 & $-2.79^{* *}$ & $-0.85^{* *}$ & -2.18 & 0.09 & $0.25 *$ & $-0.61^{* *}$ & $0.52^{* *}$ & $-0.25 *$ & $0.51^{* *}$ \\
\hline LH181 & $1.29^{* *}$ & $2.19^{* *}$ & $9.64^{* *}$ & -0.02 & $0.48^{* *}$ & $-1.57^{* *}$ & $-0.37^{* *}$ & $2.48^{* *}$ & $0.34 * *$ \\
\hline LH208 & $-1.34^{* *}$ & 0.15 & $3.10 *$ & -1.36 * & -0.33 * & $1.97^{* *}$ & $-0.28^{* *}$ & 0.01 & $0.89 * *$ \\
\hline LH212Ht & $1.66^{* *}$ & $1.19^{* *}$ & $11.06^{* *}$ & $8.28^{* *}$ & $0.77^{* *}$ & -0.01 & 0.01 & $1.18^{* *}$ & $0.51^{* *}$ \\
\hline Lp215D & $-1.42^{* *}$ & $-2.02 * *$ & $4.17^{* *}$ & $1.17^{*}$ & -0.07 & $-0.42^{* *}$ & $-0.74^{* *}$ & $0.85^{* *}$ & -0.07 \\
\hline PHJ89 & $-1.79^{* *}$ & $-1.72^{* *}$ & $-4.54^{* *}$ & $-5.22 * *$ & $-0.98^{* *}$ & $0.65^{* *}$ & -0.07 & $-0.93^{* *}$ & -0.11 \\
\hline PHK93 & $2.62 * *$ & $1.53^{* *}$ & $7.38^{* *}$ & 0.57 & $0.62^{* *}$ & $1.83^{* *}$ & 0.01 & $1.95^{* *}$ & -0.19 \\
\hline $\mathrm{LSD}_{0.05}$ & 0.17 & 0.25 & 2.58 & 1.12 & 0.24 & 0.13 & 0.08 & 0.22 & 0.21 \\
\hline $\mathrm{LSD}_{0.01}$ & 0.24 & 0.35 & 3.66 & 1.58 & 0.35 & 0.18 & 0.11 & 0.32 & 0.30 \\
\hline
\end{tabular}

${ }^{*}$ and ${ }^{* *}$ in the column represents significance at the 0.05 and 0.01 probability level, respectively. 
Number of rows per ear, number of kernel per row, and 100-kernel weight are important factors for grain yield composition. The evaluation of the 100-kernel weight revealed positive and significant GCA values for the USA inbred lines LH191, FBLA, LH181, LH212Ht, Lp215D and PHK93. The GCA effect values of the number of rows per ear were positive and significantly different for LH191, LH192, and NL001, indicating that hybrid combinations obtained by these inbred lines could increase the number of rows per ear; the GCA effect values of kernels per row indicated significant increase due to many inbreds, including LH192, PHN34, PHP76, 6F629, 6M502A, LH208, PHJ89 and PHK93. Hybrid combinations obtained by these inbred lines could increase kernels per row. For total grain yield, the positive and significant GCA coefficient indicated that hybrids developed from the corresponding inbreds may achieved higher than average grain yield (Table 10).

\subsection{General Combining Ability (GCA) Effect of China Tester Lines Suitable for Machine-Harvest Indexes and Grain Yield Characters}

From Table 11, we can see that the kernel number per row, row number per ear and grain yield GCA effect values of chang7-2 were positively significant. The GCA effects of plant height and ear height of Zheng58 were negatively significant, but the GCA effect of 100-kernel weight was positively significant. The results indicate that Zheng 58 would be beneficial in hybrids for mechanized harvest.

The GCA effect values of days to maturity, days to silking, plant height and grain moisture content at harvest were all negative significant, and GCA effect values of kernel number per row were positively significant for the tester four-144. The GCA effect values of days to maturity, days to silking, plant height, ear height and grain moisture content at harvest of four-287 were all significantly negative, and the GCA effect of 100-kernel weight was positively significant. The results showed that the hybrid combination with four-287 was easy to possess the characteristics of earlier maturity, fewer days to silking, low plant height, low ear, low moisture content at harvest, and high 100-kernel weight.

\subsection{Specific Combining Ability (SCA) of Hybrid Combination}

Among the 64 hybrid combinations, 16 had positive and significant SCA effects for yield. (Table 12). The A $\times$ A cis-hybrid combinations with good yield included LH191 $\times$ Zheng58, PHN34 $\times$ Zheng58, LH208 $\times$ Zheng58 and FBLA $\times$ four-144. The B $\times$ B cis-hybrid combinations producing increased yield included 6M502A $\times$ Chang 7-2, LH212Ht $\times$ Chang 7-2, Lp215D $\times$ Chang 7-2, RS710 $\times$ four287, LH181 $\times$ four-287 and PHK93 $\times$ four-287. Meanwhile, the A $\times$ B trans-hybrid combinations with yield increases included PHW51 $\times$ Chang 7-2, NL001 $\times$ Chang 7-2 and LH208 $\times$ four-287. The B $\times$ A trans-hybrid combinations with yield increases included $6 \mathrm{M} 502 \mathrm{~A} \times$ Zheng 58 , PHP76 $\times$ four-144 and 6 F629 $\times$ four- 144 .

Conversely, 18 had negative SCA values, which indicated decreased yields (Table 12). The A $\times$ A cis-hybrid combination with significantly decreased yield included NL001 $\times$ Zheng58 and LH208 $\times$ four-144. The B $\times$ B cis-hybrid combinations with significantly decreased yield included 6F629 $\times$ Chang7-2, LH181 $\times$ Chang7-2, PHK93 $\times$ Chang7-2, PHP76 $\times$ four-287, 6M502A $\times$ four-287, LH212Ht $\times$ four- 287. The A $\times$ B trans-hybrid combinations with significantly decreased yield includes PHN34 $\times$ Chang 7-2, FBLA $\times$ Chang7-2, PHN34 $\times$ four-287, PHW51 $\times$ four-287, FBLA $\times$ four-287 and NL001 $\times$ four-287. Meanwhile, the significantly decreased yield performers in the B $\times$ A trans-hybrid combinations included RS710 $\times$ Zheng58, LH181 $\times$ Zheng58, Lp215D $\times$ four-144 and PHJ89 $\times$ four-144. 
Table 11. The general combining ability of China tester lines for machine-harvest and yield characteristics.

\begin{tabular}{|c|c|c|c|c|c|c|c|c|c|}
\hline Line & $\begin{array}{l}\text { Days to } \\
\text { Maturity }\end{array}$ & $\begin{array}{l}\text { Days to } \\
\text { Silking }\end{array}$ & Plant Height & Ear Height & $\begin{array}{c}\text { Grain } \\
\text { Moisture at } \\
\text { Harvest }\end{array}$ & $\begin{array}{c}\text { Kernels per } \\
\text { Row }\end{array}$ & Kernel Rows & $\begin{array}{l}\text { 100-Kernel } \\
\text { Weight }\end{array}$ & Grain Yield \\
\hline Zhen58 & $1.7^{* *}$ & $0.8^{* *}$ & $-17.1^{* *}$ & $-6.9^{* *}$ & $1.0^{* *}$ & $-1.0^{* *}$ & $-0.3^{* *}$ & $0.2^{* *}$ & $-0.2^{* *}$ \\
\hline Chang7-2 & $2.1^{* *}$ & $1.3^{* *}$ & $19.8 * *$ & $19.2 * *$ & $0.9^{* *}$ & $1.8^{* *}$ & $0.9^{* *}$ & $-0.4^{* *}$ & $0.8^{* *}$ \\
\hline four-144 & $-1.7^{* *}$ & $-0.5^{* *}$ & -0.4 & $-4.7^{* *}$ & $-0.7^{* *}$ & $0.5^{* *}$ & -0.03 & $-2.0 * *$ & $-0.6^{* *}$ \\
\hline four-287 & $-2.1^{* *}$ & $-1.6^{* *}$ & $-2.3 * *$ & $-7.6^{* *}$ & $-1.2^{* *}$ & $-1.2^{* *}$ & $-0.6 * *$ & $2.2^{* *}$ & 0.01 \\
\hline $\mathrm{LSD}_{0.05}$ & 0.09 & 0.09 & 0.98 & 0.44 & 0.07 & 0.15 & 0.05 & 0.15 & 0.09 \\
\hline $\mathrm{LSD}_{0.01}$ & 0.13 & 0.12 & 1.39 & 0.62 & 0.10 & 0.21 & 0.08 & 0.21 & 0.13 \\
\hline
\end{tabular}

** in the column represents significance at the 0.01 probability level, respectively. 
Table 12. Analysis of specific combining ability of hybrid combinations for growth and yield parameters.

\begin{tabular}{|c|c|c|c|c|c|c|c|}
\hline Hybrid Combinations & Hybrid Pattern & Days to Maturity & Days to Silking & Plant Height & Ear Height & Grain Moisture at Harvest & Grain Yield \\
\hline RS710 × Zheng58 & $\mathrm{B} \times \mathrm{A}$ & $-4.25^{* *}$ & -0.07 & $-12.84^{* *}$ & $-7.52 * *$ & $0.68 *$ & $-0.47^{*}$ \\
\hline LH191 $\times$ Zheng58 & $\mathrm{A} \times \mathrm{A}$ & $-2.91^{* *}$ & $-0.61^{* *}$ & 0.63 & -0.09 & -0.03 & $0.57 *$ \\
\hline LH192 $\times$ Zheng58 & $\mathrm{A} \times \mathrm{A}$ & $-1.96^{* *}$ & $-1.11^{* *}$ & $-8.85^{* *}$ & $-5.01 * *$ & $-0.99 * *$ & -0.14 \\
\hline PHN34 $\times$ Zheng58 & $\mathrm{A} \times \mathrm{A}$ & $-2.54 * *$ & 0.06 & $8.58^{* *}$ & 0.55 & $-2.68 * *$ & $0.87 * *$ \\
\hline PHP76 $\times$ Zheng58 & $\mathrm{B} \times \mathrm{A}$ & $-1.16^{* *}$ & $0.64^{*}$ & 2.22 & $6.94 * *$ & -0.28 & 0.19 \\
\hline PHW51 $\times$ Zheng58 & $\mathrm{A} \times \mathrm{A}$ & $5.09 * *$ & $1.60^{* *}$ & $6.86 *$ & $3.64^{* *}$ & $-1.61^{* *}$ & 0.14 \\
\hline FBLA $\times$ Zheng58 & $\mathrm{A} \times \mathrm{A}$ & $1.71^{* *}$ & 0.47 & $6.55 *$ & $6.74^{* *}$ & $3.13^{* *}$ & 0.15 \\
\hline $6 \mathrm{~F} 629 \times$ Zheng 58 & $\mathrm{~B} \times \mathrm{A}$ & $2.67 * *$ & $1.22 * *$ & 3.62 & $2.43 *$ & $2.59 * *$ & -0.27 \\
\hline $6 \mathrm{M} 502 \mathrm{~A} \times$ Zheng 58 & $\mathrm{~B} \times \mathrm{A}$ & $1.21 * *$ & $0.89 * *$ & $7.21 *$ & 1.49 & $0.73^{* *}$ & $0.50^{*}$ \\
\hline NL001 × Zheng58 & $\mathrm{A} \times \mathrm{A}$ & $0.42 *$ & $-1.19 * *$ & $-10.24^{* *}$ & -7.78 ** & $-3.18^{* *}$ & $-1.01 * *$ \\
\hline LH181 $\times$ Zheng58 & $\mathrm{B} \times \mathrm{A}$ & $5.34^{* *}$ & $1.77^{* *}$ & -1.61 & $-3.04 *$ & -0.26 & $-0.95^{* *}$ \\
\hline LH208 × Zheng58 & $\mathrm{A} \times \mathrm{A}$ & $1.29 * *$ & -0.03 & $-7.31^{* *}$ & $-3.99^{* *}$ & $0.71^{* *}$ & $0.64^{* *}$ \\
\hline LH212Ht $\times$ Zheng58 & $\mathrm{B} \times \mathrm{A}$ & $-1.21 * *$ & $-1.57^{* *}$ & $7.94^{* *}$ & $9.37 * *$ & $-1.79 * *$ & -0.17 \\
\hline Lp215D $\times$ Zheng58 & $\mathrm{B} \times \mathrm{A}$ & $0.71 * *$ & -0.03 & 0.53 & -0.02 & $2.22 * *$ & 0.12 \\
\hline PHJ89 $\times$ Zheng 58 & $\mathrm{~B} \times \mathrm{A}$ & -0.08 & -0.32 & $-8.33^{* *}$ & $-4.97^{* *}$ & $0.99 * *$ & 0.10 \\
\hline PHK93 $\times$ Zheng58 & $\mathrm{B} \times \mathrm{A}$ & $-4.33^{* *}$ & $-1.73^{* *}$ & 5.03 & 1.24 & -0.25 & -0.26 \\
\hline RS710 $\times$ Chang7-2 & $\mathrm{B} \times \mathrm{B}$ & $-3.47^{* *}$ & $-1.18^{* *}$ & $-11.52 * *$ & $-15.97^{* *}$ & 0.59 * & -0.32 \\
\hline LH191 $\times$ Chang7-2 & $\mathrm{A} \times \mathrm{B}$ & $2.03 * *$ & $-1.22 * *$ & 4.87 & $7.48^{* *}$ & $-2.25^{* *}$ & -0.41 \\
\hline LH192 $\times$ Chang7-2 & $\mathrm{A} \times \mathrm{B}$ & $3.16^{* *}$ & $0.94^{* *}$ & -4.27 & $9.00 * *$ & 0.01 & 0.26 \\
\hline PHN34 $\times$ Chang7-2 & $A \times B$ & $4.08^{* *}$ & $1.11^{* *}$ & -3.19 & $3.90 * *$ & -0.08 & $-0.66^{* *}$ \\
\hline PHP76 $\times$ Chang7-2 & $\mathrm{B} \times \mathrm{B}$ & $0.95^{* *}$ & 0.19 & $-13.36^{* *}$ & $-6.13 * *$ & -0.46 & -0.22 \\
\hline PHW51 $\times$ Chang7-2 & $A \times B$ & $-3.47^{* *}$ & -0.18 & 3.76 & $-6.91 * *$ & $1.51^{* *}$ & $0.60^{* *}$ \\
\hline FBLA $\times$ Chang7-2 & $A \times B$ & $-1.01 * *$ & 0.53 * & 0.83 & $-5.58 * *$ & $1.63^{* *}$ & $-1.09 * *$ \\
\hline 6 F629 $\times$ Chang7-2 & $\mathrm{B} \times \mathrm{B}$ & $-1.88^{* *}$ & $0.94^{* *}$ & 1.99 & -1.89 & $1.60^{* *}$ & $-0.50 *$ \\
\hline $6 \mathrm{M} 502 \mathrm{~A} \times$ Chang7-2 & $\mathrm{B} \times \mathrm{B}$ & $-1.84^{* *}$ & -0.06 & 2.65 & $10.33^{* *}$ & 0.19 & 0.50 * \\
\hline NL001 $\times$ Chang7-2 & $\mathrm{A} \times \mathrm{B}$ & $2.03 * *$ & $1.03^{* *}$ & $10.24 * *$ & $6.15^{* *}$ & -0.05 & $1.69^{* *}$ \\
\hline LH181 $\times$ Chang7-2 & $\mathrm{B} \times \mathrm{B}$ & $-4.55 * *$ & $-1.52 * *$ & -4.85 & $7.68^{* *}$ & $0.83^{* *}$ & $-0.79 * *$ \\
\hline LH208 × Chang7-2 & $A \times B$ & $1.08 * *$ & -0.31 & 3.52 & $-7.55 * *$ & -0.31 & -0.04 \\
\hline LH212Ht $\times$ Chang7-2 & $\mathrm{B} \times \mathrm{B}$ & $2.08 * *$ & -0.02 & $5.44^{*}$ & $3.46^{* *}$ & 0.02 & $1.07^{* *}$ \\
\hline Lp215D $\times$ Chang7-2 & $\mathrm{B} \times \mathrm{B}$ & $-0.34^{*}$ & $0.86^{* *}$ & 1.83 & 0.99 & $-2.39^{* *}$ & $0.52^{*}$ \\
\hline PHJ89 $\times$ Chang7-2 & $\mathrm{B} \times \mathrm{B}$ & $-0.97^{* *}$ & $-0.93 * *$ & $9.02 * *$ & -0.05 & $-0.91^{* *}$ & 0.27 \\
\hline PHK93 $\times$ Chang7-2 & $\mathrm{B} \times \mathrm{B}$ & $2.12 * *$ & -0.18 & $-6.98^{*}$ & $-4.92 * *$ & 0.21 & $-0.88^{* *}$ \\
\hline RS710 $\times$ four- 144 & $\mathrm{~B} \times \mathrm{A}$ & $-1.05 * *$ & $-2.05^{* *}$ & $6.30 *$ & $-3.32 * *$ & $-2.05^{* *}$ & 0.06 \\
\hline LH191 $\times$ four-144 & $\mathrm{A} \times \mathrm{A}$ & $0.78^{* *}$ & $2.74^{* *}$ & -2.85 & $-4.01 * *$ & $1.24^{* *}$ & -0.40 \\
\hline LH192 $\times$ four-144 & $\mathrm{A} \times \mathrm{A}$ & $1.24^{* *}$ & $1.08^{* *}$ & 2.20 & $-3.68 * *$ & -0.20 & 0.03 \\
\hline
\end{tabular}


Table 12. Cont.

\begin{tabular}{|c|c|c|c|c|c|c|c|}
\hline Hybrid Combinations & Hybrid Pattern & Days to Maturity & Days to Silking & Plant Height & Ear Height & Grain Moisture at Harvest & Grain Yield \\
\hline PHN34 $\times$ four-144 & $\mathrm{A} \times \mathrm{A}$ & $-1.67^{* *}$ & $-0.59 *$ & $8.56^{* *}$ & $5.21 * *$ & $3.56^{* *}$ & 0.37 \\
\hline PHP76 $\times$ four-144 & $\mathrm{B} \times \mathrm{A}$ & $4.87 * *$ & $1.99 * *$ & $8.90 * *$ & $3.19^{* *}$ & $0.67^{*}$ & $0.69^{* *}$ \\
\hline PHW51 $\times$ four- 144 & $\mathrm{~A} \times \mathrm{A}$ & $1.62 * *$ & $-0.88^{* *}$ & $-8.83^{* *}$ & -0.93 & $1.71^{* *}$ & 0.01 \\
\hline FBLA $\times$ four-144 & $\mathrm{A} \times \mathrm{A}$ & -0.09 & $-1.51^{* *}$ & -4.16 & -1.93 & $-4.25^{* *}$ & $1.48^{* *}$ \\
\hline $6 \mathrm{~F} 629 \times$ four- 144 & $\mathrm{~B} \times \mathrm{A}$ & $-2.80 * *$ & $-3.26^{* *}$ & $-5.99 *$ & -0.69 & $-3.81^{* *}$ & $0.67 * *$ \\
\hline $6 \mathrm{M} 502 \mathrm{~A} \times$ four -144 & $\mathrm{~B} \times \mathrm{A}$ & 0.08 & -0.42 & -0.58 & $-4.10 * *$ & $-1.10^{* *}$ & $-0.43 *$ \\
\hline NL001 × four-144 & $\mathrm{A} \times \mathrm{A}$ & $-3.72 * *$ & $-1.01^{* *}$ & 3.31 & -1.55 & $1.06^{* *}$ & 0.09 \\
\hline LH181 $\times$ four-144 & $\mathrm{B} \times \mathrm{A}$ & -0.30 & $0.79 * *$ & -0.33 & -1.51 & $2.41^{* *}$ & -0.10 \\
\hline LH208 × four-144 & $\mathrm{A} \times \mathrm{A}$ & $-2.51 * *$ & $0.66 *$ & -0.88 & $6.08^{* *}$ & $-0.82 * *$ & $-1.33^{* *}$ \\
\hline $\mathrm{LH} 212 \mathrm{Ht} \times$ four -144 & $\mathrm{~B} \times \mathrm{A}$ & $0.66^{* *}$ & $0.95^{* *}$ & $-5.34 *$ & $-3.97^{* *}$ & $0.60 *$ & -0.14 \\
\hline Lp215D × four-144 & $\mathrm{B} \times \mathrm{A}$ & $-0.42 *$ & -0.17 & $-6.22 *$ & $-2.61 *$ & $-0.68 *$ & $-0.47^{*}$ \\
\hline PHJ89 × four-144 & $\mathrm{B} \times \mathrm{A}$ & $2.78^{* *}$ & $1.04^{* *}$ & $6.76 *$ & $11.94^{* *}$ & $-0.68 *$ & $-0.59 *$ \\
\hline PHK93 $\times$ four- 144 & $\mathrm{~B} \times \mathrm{A}$ & $0.53^{* *}$ & $0.62 *$ & -0.86 & 1.90 & $2.32 * *$ & 0.08 \\
\hline RS $710 \times$ four -287 & $\mathrm{~B} \times \mathrm{B}$ & $8.76^{* *}$ & $3.30 * *$ & $18.06^{* *}$ & $26.81^{* *}$ & $0.78^{* *}$ & $0.73 * *$ \\
\hline LH191 $\times$ four-287 & $\mathrm{A} \times \mathrm{B}$ & 0.10 & $-0.91^{* *}$ & -2.65 & $-3.38^{* *}$ & $1.04^{* *}$ & 0.24 \\
\hline LH192 × four- 287 & $\mathrm{~A} \times \mathrm{B}$ & $-2.45^{* *}$ & $-0.91^{* *}$ & $10.91^{* *}$ & -0.31 & $1.19^{* *}$ & -0.15 \\
\hline PHN34 $\times$ four-287 & $\mathrm{A} \times \mathrm{B}$ & 0.14 & $-0.58 *$ & $-13.95^{* *}$ & $-9.66^{* *}$ & $-0.79 * *$ & $-0.58 *$ \\
\hline PHP76 × four-287 & $\mathrm{B} \times \mathrm{B}$ & $-4.65^{* *}$ & $-2.83 * *$ & 2.24 & $-4.00 * *$ & 0.08 & $-0.65^{* *}$ \\
\hline PHW51 $\times$ four- 287 & $\mathrm{~A} \times \mathrm{B}$ & $-3.24 * *$ & -0.54 * & -1.79 & $4.20 * *$ & $-1.60^{* *}$ & -0.74 \\
\hline FBLA $\times$ four- 287 & $\mathrm{~A} \times \mathrm{B}$ & $-0.61^{* *}$ & 0.51 * & -3.22 & 0.78 & $-0.50 *$ & -0.53 * \\
\hline $6 \mathrm{~F} 629 \times$ four- 287 & $\mathrm{~B} \times \mathrm{B}$ & $2.01^{* *}$ & $1.09^{* *}$ & 0.38 & 0.14 & -0.36 & 0.10 \\
\hline $6 \mathrm{M} 502 \mathrm{~A} \times$ four- 287 & $\mathrm{~B} \times \mathrm{B}$ & $0.55^{* *}$ & -0.41 & $-9.29 * *$ & $-7.72 * *$ & 0.16 & -0.57 * \\
\hline NL001 $\times$ four-287 & $\mathrm{A} \times \mathrm{B}$ & $1.26^{* *}$ & $1.17^{* *}$ & -3.31 & $3.18^{* *}$ & $2.17^{* *}$ & $-0.76^{* *}$ \\
\hline LH181 $\times$ four -287 & $\mathrm{~B} \times \mathrm{B}$ & $-0.49 * *$ & $-1.04^{* *}$ & $6.79 *$ & $-3.13 *$ & $-2.98^{* *}$ & $1.84^{* *}$ \\
\hline LH208 × four-287 & $\mathrm{A} \times \mathrm{B}$ & 0.14 & -0.33 & 4.66 & $5.46^{* *}$ & 0.43 & $0.74^{* *}$ \\
\hline LH212Ht $\times$ four -287 & $\mathrm{~B} \times \mathrm{B}$ & $-1.53^{* *}$ & $0.63 *$ & $-8.05^{* *}$ & $-8.86^{* *}$ & $1.18^{* *}$ & $-0.75^{* *}$ \\
\hline Lp215D $\times$ four-287 & $\mathrm{B} \times \mathrm{B}$ & 0.05 & $-0.66^{*}$ & 3.86 & 1.65 & $0.85^{* *}$ & -0.18 \\
\hline PHJ89 $\times$ four2-87 & $\mathrm{B} \times \mathrm{B}$ & $-1.74 * *$ & 0.21 & $-7.45^{* *}$ & $-6.93 * *$ & 0.61 * & 0.22 \\
\hline PHK93 $\times$ four- 287 & $\mathrm{~B} \times \mathrm{B}$ & $1.68^{* *}$ & $1.30^{* *}$ & 2.80 & 1.78 & $-2.28^{* *}$ & $1.05^{* *}$ \\
\hline LSD $p \leq 0.05$ & & 0.34 & 0.50 & 5.16 & 2.23 & 0.49 & 0.43 \\
\hline $\operatorname{LSD} p \leq 0.01$ & & 0.48 & 0.70 & 7.31 & 3.17 & 0.69 & 0.60 \\
\hline
\end{tabular}

${ }^{*}$ and ${ }^{* *}$ in the column represents significance at the 0.05 and 0.01 probability level, respectively. 
There were 15 of the hybrid combinations with significantly negative SCA effect values for both days to maturity and days to silking. The $\mathrm{A} \times \mathrm{A}$ cis-hybrid combinations with short growth stage included LH191 $\times$ Zheng58, LH192 $\times$ Zheng58, PHN34 $\times$ four-144 and NL001 $\times$ four-144. The B $\times$ B cis-hybrid combinations with short growth stage included RS710 $\times$ Chang7-2, LH181 $\times$ Chang7-2, PHJ89 $\times$ Chang7-2, PHP76 $\times$ four-287 and LH181 $\times$ four-287. The more early maturing A $\times$ B trans-hybrid combinations included LH212Ht $\times$ Zheng58, PHK93 $\times$ Zheng58, RS710 $\times$ four-144 and 6 F629 $\times$ four-144. Meanwhile, the B $\times$ A trans-hybrid combinations with rapid development included LH192 $\times$ four-287 and PHW51 $\times$ four-287.

There were 14 hybrid combinations with significant negative SCA effect values for both plant height and ear height. The A $\times$ A cis-hybrid combinations with lower plants and ears included LH192 $\times$ Zheng58, NL001 $\times$ Zheng58 and LH208 $\times$ Zheng58; the B $\times$ B cis-hybrid combinations included RS710 $\times$ Chang7-2, PHP76 $\times$ Chang7-2, PHK93 $\times$ Chang7-2, 6M502A $\times$ four-287, LH212Ht $\times$ four-287 and PHJ $89 \times$ four-287; the A $\times$ B trans-hybrid combinations included PHN34 $\times$ four-287; the B $\times$ A trans-hybrid combinations included RS710 $\times$ Zheng58, PHJ89 $\times$ Zheng58, LH212Ht $\times$ four-144 and Lp215D $\times$ four-144.

There were 20 of the hybrid combinations with significant negative SCA values for grain moisture content at harvest stage. The $\mathrm{A} \times \mathrm{A}$ cis-hybrid combinations with more rapid grain moisture dry down rate included LH192 $\times$ Zheng58, PHN34 $\times$ Zheng58, PHW51 $\times$ Zheng58, NL001 $\times$ Zheng58, FBLA $\times$ four-144 and LH208 $\times$ four-144. The B $\times$ B cis-hybrid combinations with lower grain moisture content included Lp215D $\times$ Chang7-2, PHJ89 $\times$ Chang7-2, LH181 $\times$ four-287 and PHK93 $\times$ four-287. The A $\times$ B trans-hybrid combinations with decreased grain moisture content at harvest stage included LH191 $\times$ Chang7-2, PHN34 $\times$ four-287, PHW51 $\times$ four-287 and FBLA $\times$ four-287. While the B $\times$ A trans-hybrid combinations which produced drier grain included LH212Ht $\times$ Zheng58, RS710 $\times$ four-144, 6 F629 $\times$ four-144, 6M502A $\times$ four-144, Lp215D $\times$ four-144 and PHJ89 $\times$ four-144.

\subsection{Total Combining Effect (TCA) and Control Heterosis (CH) for Yield Trait}

As can be seen from Table 13, the TCA value of the yield characters in the worst to best hybrid combinations ranged from -2.62 to 3.03. The TCA effect values of the 30 best-yield and least-yield hybrid combinations were similar to the control heterosis rankings. 
Table 13. Ranking of hybrids according to their total combining ability and control heterosis

\begin{tabular}{|c|c|c|c|c|c|c|c|}
\hline Hybrid Combinations & Hybrid Pattern & Female Parent GCA Effects & Male Parent GCA Effects & SCA Effects & TCA Effects & Control Heterosis \% & Rank \\
\hline NL001 × Chang7-2 & $A \times B$ & $0.51 * *$ & $0.83^{* *}$ & $1.69^{* *}$ & 3.03 & 21.48 & 1 \\
\hline $6 \mathrm{M} 502 \mathrm{~A} \times$ Chang7-2 & $\mathrm{B} \times \mathrm{B}$ & $1.47^{* *}$ & $0.83^{* *}$ & $0.50 *$ & 2.80 & 19.64 & 2 \\
\hline LH212Ht $\times$ Chang7-2 & $\mathrm{B} \times \mathrm{B}$ & $0.51 * *$ & $0.83^{* *}$ & $1.07^{* *}$ & 2.41 & 15.93 & 3 \\
\hline LH181 $\times$ four- 287 & $\mathrm{~B} \times \mathrm{B}$ & $0.34^{* *}$ & 0.01 & $1.84^{* *}$ & 2.19 & 14.05 & 4 \\
\hline PHW51 $\times$ Chang7-2 & $A \times B$ & $0.48^{* *}$ & $0.83^{* *}$ & $0.60 * *$ & 1.91 & 11.60 & 5 \\
\hline $6 \mathrm{M} 502 \mathrm{~A} \times$ Zheng58 & $\mathrm{B} \times \mathrm{A}$ & $1.47^{* *}$ & $-0.18^{* *}$ & $0.50 *$ & 1.79 & 11.21 & 6 \\
\hline LH208 $\times$ Chang7-2 & $A \times B$ & $0.89 * *$ & $0.83^{* *}$ & -0.04 & 1.68 & 9.79 & 7 \\
\hline LH208 $\times$ four- 287 & $A \times B$ & $0.89 * *$ & 0.01 & $0.74^{* *}$ & 1.64 & 9.50 & 8 \\
\hline LH208 × Zheng58 & $\mathrm{A} \times \mathrm{A}$ & $0.89 * *$ & $-0.18^{* *}$ & $0.64^{* *}$ & 1.35 & 6.94 & 9 \\
\hline Lp215D $\times$ Chang7-2 & $\mathrm{B} \times \mathrm{B}$ & -0.07 & $0.83^{* *}$ & $0.52 *$ & 1.28 & 6.44 & 10 \\
\hline FBLA $\times$ four- 144 & $\mathrm{~A} \times \mathrm{A}$ & $0.42 * *$ & $-0.64^{* *}$ & $1.48^{* *}$ & 1.26 & 5.96 & 11 \\
\hline PHJ89 × Chang7-2 & $\mathrm{B} \times \mathrm{B}$ & -0.11 & $0.83^{* *}$ & 0.27 & 0.99 & 3.86 & 12 \\
\hline $6 \mathrm{M} 502 \mathrm{~A} \times$ four- 287 & $\mathrm{~B} \times \mathrm{B}$ & $1.47^{* *}$ & 0.01 & -0.57 * & 0.91 & 3.36 & 13 \\
\hline PHK93 $\times$ four-287 & $\mathrm{B} \times \mathrm{B}$ & -0.19 & 0.01 & $1.05^{* *}$ & 0.87 & 2.96 & 14 \\
\hline LH192 $\times$ Chang7-2 & $\mathrm{A} \times \mathrm{B}$ & $-0.49^{* *}$ & $0.83^{* *}$ & 0.26 & 0.60 & 0.76 & 15 \\
\hline LH181 $\times$ Zheng58 & $\mathrm{B} \times \mathrm{A}$ & $0.34^{* *}$ & -0.18 & $-0.95^{* *}$ & -0.79 & -10.95 & 50 \\
\hline PHK93 $\times$ four-144 & $\mathrm{B} \times \mathrm{A}$ & -0.19 & $-0.64^{* *}$ & 0.08 & -0.75 & -11.18 & 51 \\
\hline LH192 $\times$ Zheng58 & $\mathrm{A} \times \mathrm{A}$ & $-0.49^{* *}$ & $-0.18^{* *}$ & -0.14 & -0.81 & -11.61 & 52 \\
\hline PHN34 $\times$ four-287 & $\mathrm{A} \times \mathrm{B}$ & $-0.28 *$ & 0.01 & -0.58 * & -0.85 & -11.79 & 53 \\
\hline LH208 $\times$ four- 144 & $\mathrm{~A} \times \mathrm{A}$ & $0.89^{* *}$ & $-0.64 *$ & $-1.33^{* *}$ & -1.08 & -13.48 & 54 \\
\hline 6 F629 $\times$ Zheng58 & $\mathrm{B} \times \mathrm{A}$ & $-0.63^{* *}$ & $-0.18^{* *}$ & -0.27 & -1.08 & -13.65 & 55 \\
\hline LH192 $\times$ four-144 & $A \times A$ & $-0.49^{* *}$ & $-0.64^{* *}$ & 0.03 & -1.10 & -14.19 & 56 \\
\hline Lp215D $\times$ four-144 & $\mathrm{B} \times \mathrm{A}$ & -0.07 & $-0.64^{* *}$ & $-0.47^{*}$ & -1.18 & -14.32 & 57 \\
\hline PHP76 $\times$ four-287 & $\mathrm{B} \times \mathrm{B}$ & $-0.56^{* *}$ & 0.01 & $-0.65^{* *}$ & -1.2 & -14.59 & 58 \\
\hline RS $710 \times$ four- 287 & $\mathrm{~B} \times \mathrm{B}$ & $-1.97^{* *}$ & 0.01 & $0.73^{* *}$ & -1.23 & -15.12 & 59 \\
\hline PHJ89 $\times$ four-144 & $\mathrm{B} \times \mathrm{A}$ & -0.11 & $-0.64^{* *}$ & $-0.59 *$ & -1.34 & -16.11 & 60 \\
\hline LH191 $\times$ four-144 & $\mathrm{A} \times \mathrm{A}$ & $-0.31^{* *}$ & $-0.64^{* *}$ & -0.40 & -1.35 & -16.17 & 61 \\
\hline RS710 × Chang7-2 & $\mathrm{B} \times \mathrm{B}$ & $-1.97 * *$ & $0.83^{* *}$ & -0.32 & -1.46 & -16.81 & 62 \\
\hline RS710 $\times$ four- 144 & $\mathrm{~B} \times \mathrm{A}$ & $-1.97^{* *}$ & $-0.64^{* *}$ & 0.06 & -2.55 & -26.35 & 63 \\
\hline RS710 $\times$ Zheng58 & $\mathrm{B} \times \mathrm{A}$ & $-1.97^{* *}$ & $-0.18^{* *}$ & $-0.47^{*}$ & -2.62 & -26.89 & 64 \\
\hline
\end{tabular}

${ }^{*}$ and ${ }^{* *}$ in the column represents significance at the 0.05 and 0.01 probability level, respectively. 
Among the top fifteen TCA effect values, there were two $\mathrm{A} \times \mathrm{A}$ cis-hybrid combinations, seven $\mathrm{B} \times \mathrm{B}$ cis-hybrid combinations, five $\mathrm{A} \times \mathrm{B}$ trans-hybrid combinations, and one $\mathrm{B} \times \mathrm{A}$ trans-hybrid combination. The TCA effect values that increased yield can be divided into the following three categories:

(1) Both parental GCA and hybrid SCA effects were large, for hybrid combinations NL001 $\times$ Chang7-2, 6M502A $\times$ Chang7-2, LH212Ht $\times$ Chang7-2, PHW51 $\times$ Chang7-2, Lh181 $\times$ four-287 and LH208 $\times$ four- 287 .

(2) Complementary parental GCA effects with a positive hybridization combination SCA effect as observed for the hybrids 6M502A $\times$ Zheng58, LH208 $\times$ Zheng58, Lp215D $\times$ Chang7-2, FBLA $\times$ four-144, PHJ89 $\times$ Chang7-2, PHK93 $\times$ four-287 and LH192 $\times$ Chang7-2.

(3) Parental GCA effect values were large with small SCA values, as found in the hybrids LH208 $\times$ Chang7-2 and 6M502A $\times$ four-287.

The 15 hybrids with the lowest TCA effect values can be divided into the following four categories:

(1) The complementary value of parental GCA effect value and the large value for the SCA effect of hybrid combination, such as for RS $710 \times$ four- 287 .

(2) The complementary value of parental GCA effects and a small value for the SCA effect of hybrid combination, such as LH181 $\times$ Zheng58, PHN34 $\times$ four-287, LH208 $\times$ four-144, PHP76 $\times$ four-287, and RS710 $\times$ Chang7-2.

(3) Both parents with small GCA effect values and hybrid combinations with positive SCA effect values, such as hybrids PHK93 $\times$ four-144, LH192 $\times$ four-144, and RS710 $\times$ four-144.

(4) Both parents with small GCA and hybrid with low SCA effect values, such as LH192 $\times$ Zheng58, 6F629 $\times$ Zheng58, Lp215D $\times$ four-144, PHJ89 $\times$ four-144, LH191 $\times$ four-144, and RS710 $\times$ Zheng58.

In Table 13, all the control heterosis values were the mean values of two locations, and ranged from $-26.89 \%$ to $21.48 \%$. There were 15 hybrid combinations with positive heterosis, 2NL001 $\times$ chang7-2, 6M502A $\times$ chang7-2, LH212Ht $\times$ chang7-2, LH181 $\times$ four287, PHW51 $\times$ chang7-2, 6M502A $\times$ Zheng58, LH208 $\times$ chang7-2, LH208 $\times$ Zheng58, lh215d $\times$ chang7-2, FBLA $\times$ four-144, PHJ89 $\times$ chang7-2, 6M502A $\times$ four287, PHK93 $\times$ four287, LH192 $\times$ chang7-2 (Table 13), indicating that these hybrids had better yield than the standard of Zhengdan 958.

\section{Discussion}

\subsection{Improvement and Utilization of USA Germplasm}

The introduction of exotic germplasm was an important way to enrich genetic diversity for China maize crop production. It has been stated that the potential utilization of inbred lines cannot be judged according to the strengths and weaknesses of the inbred plant growth, but needs to be identified based on the analysis of combining ability [11-13]. From Tables 10 and 11, we can see that the North American inbred lines are genetically distinct from the inbred lines of China, and there was a wide regional gap between them. There were significant differences in GCA effect values of the inbred when grown at different locations, which indicates that American inbred lines perform well in comprehensive traits such as yield. In the process of improving, selecting, and matching inbred lines to make improved hybrids, the target traits can be selected according to the GCA, and the grouping of American inbred lines can be determined. On the basis of plant growth, development, and heterotic patterns, according to the principle of complementary characteristics of the same group, successful maize production populations have been constructed with superior inbred lines, and the frequency of superior alleles has been improved by selective repetitive breeding [14-17].

\subsection{Classification of USA Germplasm}

By analyzing the SCA effect value of 64 hybrid combinations, it was found that there were both cis and trans combinations of heterotic groups in which the yield SCA effect value was positive and 
significant. Heterosis existed between the USA inbred lines SS group and the China A group, and between the USA inbred lines NSS group and the China B group. This was due to the differences in the Germplasm Foundation of the China A group and the B group, and also the SS group and NSS group in the United States. When using the USA inbred lines, the combining ability of USA inbred lines must be determined on the basis of local indigenous inbred lines. To identify the classification of American inbred lines, and the heterosis group of USA inbreds, in breeding the second-cycle inbred line, the cis hybrid combination is usually used to improve the group.

\subsection{Combining Ability and Control Heterosis of USA Germplasm}

The TCA effect value of a hybrid was the same trend as its ranking compared to control heterosis. The TCA values of hybrid combinations with yields greater than the control hybrid were all positive, and the TCA values of hybrid combinations yielding less than the control were all negative. The value of TCA can be used as an index in hybrids selection [18,19]. In the top 15 TCA value hybrid combinations, the SCA effect value was mostly positive. There were 8 hybrid combinations with positive GCA values of parental yield, and 8 hybrid combinations with positive and negative GCA values of parental yield. The results showed that hybrid combinations with high heterosis required higher SCA and GCA effect values [20]. The selection of GCA effect value of parental yield should be paid attention to in heterotic crossing combinations, ensuring that at least one parent yield GCA effect value is positive, and SCA effect value should not be too low.

\section{Conclusions}

The best combiner inbred lines from USA were RS710, PHP76, FBLA, and PHJ89. These materials had great potential for breeding early maturing, had high density tolerance, and were suitable for machine-harvest hybrids. The best USA inbred lines with high GCA in yield traits were 6M502A, LH208, NL001, LH212Ht, PHW51, FBLA, and LH181. These inbred lines had great potential in breeding high-yield hybrids. The use of parental combining ability information will ease the process of making superior hybrids. The inbred line Chang7-2 promoted a high-yield hybrid combination ability. Meanwhile, the inbred line four-287 led to hybrid combinations suitable for machine harvesting. The TCA value could be used as an index to evaluate the heterosis of hybrid combinations without growing the control hybrid for comparison. The best hybrid combination were NL001 $\times$ Chang7-2, 6 M502A $\times$ Chang7-2, LH212Ht $\times$ Chang7-2, LH181 $\times$ four-287, PHW51 $\times$ Chang7-2, 6M502A $\times$ Zheng58, LH208 $\times$ Chang7-2, LH208 $\times$ four-287, LH208 $\times$ Zheng58, Lp215D $\times$ Chang7-2, FBLA $\times$ four-144. Furthermore, these hybrid combinations have potential for further commercial development.

Author Contributions: J.-y.S., J.-l.G. and X.-f.Y. conceived and designed the experiments; J.L., Y.F. and D.W. performed the experiments; Z.-j.S. performed the statistical analysis; J.-y.S. wrote the paper.

Funding: This study was funded by the National Key Research and Development Program of China (2017YFD0300802, 2016YFD0300103), the Maize Industrial Technology System Construction of Modem Agriculture of China (CARS-02-63) and the Fund of Crop Cultivation Scientific Observation Experimental Station in North China Loess Plateau (25204120) of China.

Acknowledgments: We would like to thank the Maize High-Yield and High-Efficiency Cultivation Team for field and data collection, and especially Juliann Seebauer for manuscript revisions.

Conflicts of Interest: The authors declare no conflicts of interest.

\section{References}

1. Zhang, S.H.; Tian, Q.Z.; Li, X.H. Advancement of maize germplasm improvement and relevant research. Maize Sci. 2006, 14, 1-6. [CrossRef]

2. Chen, D.Y.; Jing, X.Q.; Wang, X.J. Discussion on the breeding for mechanical harvesting and density tolerant maize hybrids. Crops 2014, 2, 13-15. [CrossRef]

3. Li, C.; Qiao, J.F.; Gu, L.M. Analysis of maize biological traits which affected corn kernel mechanically harvesting qualities. Acta Agric. Boreal. Sin. 2015, 30, 164-169. [CrossRef] 
4. Zhang, S.H.; Xu, W.P.; Li, M.S. Challenge and opportunity in maize breeding program. Maize Sci. 2008, 16, 1-5. [CrossRef]

5. Zhao, W.Y.; Liu, X.; Wang, D.X. Experience and lesson of American maize varieties resource utility. China Seed Ind. 2011, 10, 50-51. [CrossRef]

6. Li, H.M.; Hh, R.F.; Zhang, S.H. The impacts of US and CGIAR's germplasm on maize production in China. Sci. Agric. Sin. 2005, 38, 2189-2197.

7. Yong, H.J.; Wang, J.J.; Zhang, D.G. Characterization and potential utilization of maize populations in America region. Hereditas (Beijing) 2013, 35, 703-713. [CrossRef] [PubMed]

8. Pan, T.Z.; Gao, J.L.; Su, Z.J. Comprehensive evaluation of agronomic traits based on principal component analysis of maize hybrids. North. Agric. 2016, 44, 1-8. [CrossRef]

9. Federer, W.T.; Wolfinger, R.D. SAS code for recovering inter effect information in experiments with incomplete block and lattice rectangle designs. Agron. J. 1998, 90, 545-551. [CrossRef]

10. Geraldi, I.O.; Miranda Filho, J.B. An adapted model for the analysis of partial diallel crosses. Braz. J. Genet. 1988, 11, 419-430.

11. Hallauer, A.R.; Carena, M.J.; Miranda Filho, J.B.; Carena, M.J. Testers and Combining Ability, Quantitative Genetics in Maize Breeding, 8th, ed.; Iowa State University Press: Ames-Iowa, IA, USA, 1988; pp. 383-418, ISBN 978-1-4419-0765-3.

12. Duvick, D.N.; Cassman, K.G. Post-green revolution trends in yield potential of temperate maize in the North-Central United States. Crop Sci. 1999, 39, 1622-1630. [CrossRef]

13. Duvick, D.N. The contribution of breeding to yield advances in maize (Zea mays L.). Adv. Agron. 2005, 86, 91-97. [CrossRef]

14. Mao, J.C.; Zhang, S.H.; Li, X.T. The methodology for maize inbred line with high yield selection and high combining ability. Sci. Agric. Sin. 2006, 39, 872-878.

15. Gao, X.D.; Zhou, X.M.; Gao, H.M. Combining ability of main agronomic traits and heterosis of European maize germplasm BRC. Maize Sci. 2015, 23, 28-33. [CrossRef]

16. Sun, F.C.; Feng, Y.; Su, E.H. Analysis of combining ability of yield of fractional inbred line of main corn varieties in inner mongolia and study on their genetic relationship. Acta Agric. Boreal. Sin. 2011, 26, 119-123.

17. Li, M.S.; Zhang, S.H.; Li, X.H. Study on heterotic groups among maize inbred lines based on SCA. Sci. Agric. Sin. 2002, 35, 600-605.

18. Chen, C.; Yuan, H.Y.; Lei, Y.T. Analysis of yield combining ability and heterosis of selective lines form the improve maize population MM. J. Northwest. A F Univ. 2013, 41, 93-98. [CrossRef]

19. Cui, C.; Gao, J.L.; Yu, X.F. Combining ability of traits related to nitrogen use efficiency in eighteen maize inbred lines. Acta Agon. Sin. 2014, 40, 838-849. [CrossRef]

20. Gou, C.M.; Yu, S.Q.; Huang, N. Analysis on combining ability of 17 inbred lines from maize landraces. Acta Agric. Sin. 2015, 30, 175-182. [CrossRef] 